\title{
Differences in the Prevalence of Giardia intestinalis as a Generalized Pruritus Etiologic Factor Between Geographic Regions in Turkey
}

\author{
Fatma Pelin CENGiZ, Nazan EMIROĞLU, Anıl Gülsel BAHALI, Özlem SU, Nahide ONSUN \\ Department of Dermatological and Venereal Diseases, Bezmialem Vakıf University, İstanbul, Turkey
}

\section{ABSTRACT}

Objective: Giardia intestinalis is a protozoan parasite of the gastrointestinal tract that is widely distributed worldwide. Patients with $G$. intestinalis are usually asymptomatic; however, the presence of the parasite may lead to a variety of clinical manifestations, including skin lesions.

Methods: In this study, 100 cases of generalized pruritus who were followed up in the dermatology outpatient clinics of Kars State Hospital and Bezmialem Vakif University between September 2013 and December 2013 were evaluated to retrospectively determine the incidence of $G$. intestinalis.

Results: A total of 100 patients were analyzed in this study, and 38\% of the patients in Kars were found to have the parasite. There were no cases of Giardia in Istanbul. There was a statistically significant difference in parasite prevalence between geographic regions ( $<<0.05$ ). Overall, $37.9 \%$ of men and $38.0 \%$ of women tested positive for parasites. No significant difference was found in parasite prevalence by sex $(\mathrm{p}>0.05)$. The mean duration of generalized pruritus was $6.52 \pm 2.13$ months.

Conclusions: $G$. intestinalis is more common in the Eastern Anatolian region of Turkey than in other regions. Patients with generalized pruritus should be investigated for $G$. intestinalis infection, especially in this region.

Keywords: Region, giardia, pruritus

\section{Introduction}

Generalized pruritus is one of the most common causes of dermatology outpatient visits. It can be observed in patients with a primary skin disease, underlying systemic diseases without any primary skin disease, or idiopathy. Generalized pruritus may accompany primary skin diseases such as urticaria, dermatitis herpetiformis, scabies, atopic dermatitis, and drug eruption. Diseases that most commonly accompany generalized pruritus, which is a systemic disease, are iron deficiency anemia, hepatic or cholestatic diseases, polycythemia rubra vera, diabetes mellitus, thyroid diseases, hypercalcemia, renal diseases, malignancy, allergic-infectious causes, and psychiatric diseases (1-3).

Giardia intestinalis causes 2.8 million intestinal infections per year (4). It is the most common parasitic cause of diarrhea in humans. Other than diarrhea, symptoms include abdominal pain, cramps, anorexia, vomiting, and weakness. Epidemiological and clinical studies have shown that 20\%-84\% of infected individuals are asymptomatic (5). Although parasitic infections often cause visible skin lesions, making a diagnosis is sometimes difficult. It has been reported that the most common skin symptoms of giardiasis are urticaria and angioedema $(6,7)$. Apart from these, oral ulcers, pruritus, and atopic dermatitis have been indicated to accompany giardiasis (7). In this study, we aimed to determine the frequency of $G$. intestinalis in patients with treatment-resistant generalized pruritus in two different geographical regions.

\section{Methods}

The laboratory data of 100 patients who had a complaint of pruritus and were admitted to the Dermatology Polyclinic of Kars State Hospital and Bezmialem Vakıf University between September 2013 and December 2013 were evaluated retrospectively. Fecal parasite examinations were requested from the microbiology laboratory in order to detect the etiology of generalized pruritus in patients. The patients' gaita samples were examined through the native-lugol, sedimentation method (Formol-Ethyl Acetate Sedimentation) and Trichrome staining without any delay. Written informed consent was received from the patients. Because the files were searched in the system retrospectively, no ethics committee approval was 
obtained. The study was conducted in accordance with the provisions of the Helsinki Declaration.

\section{Statistical analysis}

A $p$ value of $<0.05$ was accepted as statistically significant. Analyses were made with the Statistical Package for the Social Sciences 15.0 (SPSS Inc.; Chicago, IL, USA) for Windows in Istanbul, Turkey. Fisher's exact test was used to examine the relationship between the categorical variables. Numerical variables are given as the mean and standard deviation.

\section{Results}

Of the fifty patients examined in Kars, 29 were men (58\%) and 21 were women (42\%); 25 of the patients examined in İstanbul were men (50\%) and 25 were women $(50 \%)$. The ages of the patients participating in the study ranged from 8 to 65 years. The mean age was $38.56 \pm 7.65$ years in Kars and $33.72 \pm 9.55$ years in İstanbul. While Giardia was not found in patients examined in İstanbul, 19 patients (38\%) examined in Kars were found to have Giardia lamblia cysts in their stool samples. There is a statistically significant difference between the two regions in terms of the incidence of Giardia $(\mathrm{p}<0.05)$. Of the patients diagnosed with Giardia in Kars, eight were women (38\%) and 11 were men (37.9\%). There was no significant difference in the rate of incidence of parasites according to gender $(p>0.05)$. The gastrointestinal findings of the patients diagnosed with Giardia cysts were questioned. While at least one of the symptoms of diarrhea, abdominal pain, anorexia, and weakness was found in seven of the patients (36.8\%), 12 patients $(63.2 \%)$ were asymptomatic. There was no correlation between the patients' being symptomatic and the duration of generalized pruritus $(p>0.05)$.

When the duration of generalized pruritus was questioned in a hundred patients, the average was found to be $6.52 \pm 2.13$ months in Kars and 4.62 \pm 1.15 months in İstanbul (3-19 months). No statistically significant relationship was found between the patients' complaints of pruritus and the detection rate of Giardia ( $\mathrm{p}>0.05)$ (Table 1).

\section{Discussion}

G. intestinalis ( $G$. duodenalis or $G$. lamblia) is the second most common enteric infection worldwide after amoebiasis (4). Patients are usually asymptomatic, and $G$. does not cause a severe infection, which is transmitted via the fecal-oral way. Infections can be waterborne or foodborne. Young age, poor hygiene, malnutrition, hypochlorhydria, contaminated water resources, and immunodeficiencies are high risk factors for giardiasis (8).

Urticaria, angioedema, oral ulcers, pruritus, atopic dermatitis, lichen planus-like skin eruptions, mucocutaneous eruption, erythema nodosum, and granuloma are signs that are observed on the skin $(7,9,10)$.

Several studies have investigated the incidence of intestinal parasites in Turkey (11-14). In the study that Karaman et al. conducted, $14.6 \%$ of patients with generalized pruritus were
Table 1. General Characteristics of Patients

\begin{tabular}{|l|c|c|c|}
\hline Number of patients & Female & Male & Total \\
\hline Average age & $21(42 \%)$ & $29(58 \%)$ & 50 \\
& $\begin{array}{c}34.29 \pm 12.75 \\
\text { years }\end{array}$ & $\begin{array}{c}39.84 \pm 10.43 \\
\text { years }\end{array}$ & $\begin{array}{c}38.56 \pm 7.65 \\
\text { years }\end{array}$ \\
\hline Giardia cysts positivity & $8(38 \%)$ & $11(37.9 \%)$ & $19(38 \%)$ \\
Symptom positivity & $3(42.9 \%)$ & $4(57.1 \%)$ & $7(36.8 \%)$ \\
Pruritus duration & $4.81 \pm 2.53$ & $7.62 \pm 1.83$ & $6.52 \pm 2.13$ \\
& months & months & months \\
\hline
\end{tabular}

found to have intestinal parasites (14). According to the gender and age groups, there was no significant difference in the incidence of parasites in this study $(\mathrm{p}>0.05)$. G. intestinalis was detected in 12 patients (17.6\%). It is the second most common intestinal infection after E. Coli. G. intestinalis positivity was found to be significantly higher in patients with anal and generalized pruritus than those with it $(\mathrm{p}<0.05)$.

It is known that parasitic diseases may cause eosinophilia and urticaria with increased IgE levels. Giardia rarely invades the intestinal wall, and it usually does not cause inflammation. Giardia-specific immunoreaction has shown that secretory IgA is important for eliminating parasites (15). Humoral immunity is the most important factor in the resolution of Giardia infestation. Similar to urticaria, cutaneous manifestations of Giardia invasion are considered to be associated with type 2 immune response $(16,17)$. In a study in Poland, the most common skin finding of giardiasis was nummular eczema (18). Hagel et al. (19) evaluated children with Giardia cysts and Ascaris eggs in their feces in terms of allergic symptoms and found that the ratio of urticaria was statistically significantly higher in patients with Giardia cysts than in those with Ascaris eggs.

Giacometti et al. (16) detected G. intestinalis in $4.1 \%$ of 218 patients with chronic urticaria, atopic dermatitis, and unknown itching and determined that there was a significant association between the presence of this protozoan and skin findings. Considering that the cutaneous manifestations of Giardia are related to type 2 immune response, the levels of interleukin (IL)-4, IL-5, IL-9, and IL-13 cytokines increase in the Th2 pathway $(15,16)$. These cytokines stimulate eosinophils, mast cells, and basophils. These increased cytokine levels result in allergic inflammation, elevated IgE levels, and chronic eosinophilic inflammation. In this manner, giardiasis is considered to cause generalized pruritus.

In our study, Giardia cysts were detected in $38 \%$ of patients with generalized pruritus in Kars but not in Istanbul. This rate is higher than those reported in previous studies. The widespread occurrence of giardiasis in the Eastern Anatolia region has been attributed to poor hygiene, increased animal husbandry in the region, and water resources that are more contaminated with animal waste than other regions. When a treatment was initiated for patients with Giardia, pruritus was observed to regress. 


\section{Conclusion}

G. intestinalis should be considered in etiology, particularly in patients with generalized pruritus in the Eastern Anatolia. Routine examinations for parasites are required in generalized and resistant pruritus cases.

Ethics Committee Approval: Authors declared that the research was conducted according to the principles of the World Medical Association Declaration of Helsinki "Ethical Principles for Medical Research Involving Human Subjects", (amended in October 2013).

Informed Consent: Informed consent was obtained from patients who participated in this study.

Peer-review: Externally peer-reviewed.

Author Contributions: Concept - F.P.C., N.E.; Design - F.P.C., N.E.; Supervision - N.O., Ö.S.; Funding - A.G.B, N.E.; Materials - F.P.C., N.E.; Data Collection and/or Processing - N.E., A.G.B.; Analysis and/or Interpretation - F.P.C., N.O.; Literature Review - N.E., Ö.S.; Writing - F.P.C., N.O.; Critical Review - N.O., Ö.S.

Conflict of Interest: No conflict of interest was declared by the authors.

Financial Disclosure: The authors declared that this study has received no financial support.

\section{References}

1. Paul R, Jansen CT. Itch and malignancy prognosis in generalized pruritus: A 6-year follow up of 125 patients. J Am Acad Dermatol 1987; 16: 1179-82. [CrossRef]

2. Odom RB, James WD, Berger TG, ed. Andrew's Diseases of The Skin: clinical dermatology. 9th ed, 2000: 49-52.

3. Lober CWL. Should the patient with generalized pruritus be evaluated for malignancy? J Am Acad Dermatol 1988; 19: 350-2. [CrossRef]

4. Ali SA, Hill DR. Giardia intestinalis. Curr Opin Infect Dis 2003; 16 : 453-60. [CrossRef]

5. Majewska AC. Epidemiologiczno-kliniczne cechy gardiozy. Prz Epid 2000; 54: 230-4.
6. Sanchez-Carpintero I, Vazquez-Doval FJ. Cutaneous lesions in giardiasis. Report of two cases. Br J Dermatol 1998; 139: 152-3.

7. Vassallo C, Brazzelli V, Martinoli S, Ardigo M, et al. Chronic Giardia intestinalis infection presenting with clinical features mimicking lichen planus. Acta Derm Venereol 2001; 81: 309-10. [CrossRef]

8. Khatami SS, Mukunda B, Ravakhah K. Coinfection with Giardia lamblia and Clostridium difficile after use of ranitidine. Am J Med Sci 2004; 327: 91-3. [CrossRef]

9. Lammintausta K, Kotilainen P, Hohenthal U, Talve L. A patient with a mucocutaneous eruption and intestinal giardiasis. Acta Derm Venereol 2001; 81: 310-1. [CrossRef]

10. Steiger U, Weber M. Ungewohnliche Ursache von Erythema nodosum, Pleuraerguss und reaktiver Arthritis: Giardia lamblia. Scheiz Rundsch Med Prax 2002; 91: 1091-2. [CrossRef]

11. Babür C, Kılıç S, Özkan AT, Esen B. Refik Saydam Hıfzısıhha Merkezi Başkanlığı parazitoloji Laboratuvarı'nda 1995-2000 yıllarında saptanan bağırsak parazitlerinin değerlendirilmesi. Türkiye Parazitol Derg 2002; 26: 286-91.

12. Doğruman Al F, Adışen E, Kuştimur S, Gürer MA. Ürtiker Etyolojisinde Protozoonların Yeri. 2009; 2: 136-9.

13. Kapdağlı A, Ertabaklar H, Yaman S, Ertuğ S. Adnan Menderes Üniversitesi Tip Fakültesi Parazitoloji laboratuvarına 2002 yılında başvuran olgulardaki bağırsak parazitlerinin değerlendirilmesi. Türkiye Parazitol Derg 2003; 27: 31-4.

14. Karaman Ü, Şener S, Özer A, Turan A. Kaşıntılı Dermatozlarda Bağırsak Parazitlerinin Görülme Sıklığı. Fırat Sağlık Hizmetleri Dergisi 2010; 15: 59-68.

15. Eckmann L. Mucosal defences against Giardia. Parasite Immunol 2003; 25: 259-70. [CrossRef]

16. Giacometti A, Cirioni O, Antonicelli L, D’Amato G, Silvestry C, Prete MSD, et al. Prevalence of intestinal parasites among individuals with allergic skin diseases. J Parasitol 2003; 89: 490-2. [CrossRef]

17. Jimenez JC, Fontaine J, Grzych JM, Dei-Cas E, Capron M. Systemic and mucosal responses to oral administration of excretory and secretory antigens from Giardia intestinalis. Clin Diagn Lab Immunol 2004; 11: 152-60. [CrossRef]

18. Ratka P, Sloboda T. Skin changes in lambliasis. Preliminary report. Przegl Dermatol 1984; 71: 437-41.

19. Hagel I, Lynch NR, Di prisco MC, Lopez RI, Garcia MC. Allergic reactivity of children of different socieconomic levels in tropical populations. Int Arch Allergy Imm 1993; 101: 209-14. [CrossRef] 